\title{
Prepartal standing behavior as a parameter for early detection of postpartal subclinical ketosis associated with inflammation and liver function biomarkers in peripartal dairy cows
}

\author{
S. Rodriguez-Jimenez, ${ }^{*}$ K. J. Haerr,† E. Trevisi,ł J. J. Loor,† F. C. Cardoso,† and J. S. Osorio*1 \\ *Department of Dairy and Food Sciences, South Dakota State University, Brookings 57007 \\ †Department of Animal Sciences and Division of Nutritional Sciences, University of Illinois, Urbana 61801 \\ łIstituto di Zootecnica, Facoltà di Scienze Agrarie, Alimentari e Ambientali, Università Cattolica del Sacro Cuore, 29122, Piacenza, Italy
}

\begin{abstract}
A degree of negative energy balance is commonly experienced by cows during early lactation. This physiological state, if pronounced or prolonged, leads to partial oxidation of nonesterified fatty acids as an energy source and, consequently, increasing blood $\beta$-hydroxybutyrate (BHB) concentrations and potentially development of ketosis in postpartal dairy cows. Twenty-four multiparous Holstein cows received a common prepartal and postpartal diet. Cows were fitted with an accelerometer mounted laterally on the distal left hind leg using vet wrap from -30 to $15 \mathrm{~d}$ relative to parturition. A retrospective analysis was performed using the postpartal $\mathrm{BHB}$ data at 8 time points from 0 to $15 \mathrm{~d}$ in milk measured with the Precision Xtra (Abbott Diabetes Care, Alameda, CA). Cows with an average blood $\mathrm{BHB}<1.4 \mathrm{mmol} / \mathrm{L}$ were designated nonketotic (NONKET; $\mathrm{n}=12$ ), and those with $\geq 1.4$ $\mathrm{mmol} / \mathrm{L}$ were designated ketotic $(\mathrm{KET} ; \mathrm{n}=12)$. A total of 8 samples per cow were used for this analysis. Subsequent analyses of behavioral patterns and blood biomarkers were performed using this group effect. On average, blood BHB reached subclinical levels (1.4 \pm $0.3 \mathrm{mmol} / \mathrm{L}$; mean \pm standard error of the mean) at $3 \mathrm{~d}$ postpartum for all cows in this study. Behavioral patterns were obtained from accelerometer data, and correlation analysis was performed between these behaviors such as standing and lying time from -30 to $3 \mathrm{~d}$ relative to parturition and blood BHB concentration at $3 \mathrm{~d}$ postpartum. The strongest correlation was obtained between standing time at $3 \mathrm{~d}$ before calving and blood $\mathrm{BHB}$ at $3 \mathrm{~d}$ postpartum. Dry matter intake was greater (ca. $3 \mathrm{~kg} / \mathrm{d}$ ) in NONKET cows than in KET cows. An interaction of group $\times$ time for milk yield resulted in an overall increase of $5.7 \mathrm{~kg} / \mathrm{d}$ in NONKET cows
\end{abstract}

Received December 6, 2017.

Accepted May 13, 2018.

${ }^{1}$ Corresponding author: Johan.Osorio@sdstate.edu in comparison with KET. The blood concentrations of biomarkers for liver function ( $\gamma$-glutamyltransferase and glutamic-oxaloacetic transaminase), inflammation (IL-6), and metabolism (nonesterified fatty acids) were increased at various time points in KET cows in comparison with NONKET during the transition period. Overall, lower bilirubin in NONKET cows than in KET further confirmed an impaired liver function in the latter group of cows. Our findings revealed the potential for establishing correlations between prepartal behavioral patterns derived from accelerometer data and postpartal subclinical ketosis, and further confirming the latter by physiological alterations in biomarkers related to inflammation and liver function. Our data also indicate that cows with a predisposition to postpartal subclinical or clinical ketosis will remain standing for fewer hours during the days leading to parturition, which decreased DMI, and this condition was further reflected in lower milk yield.

Key words: transition cow, subclinical ketosis, behavior

\section{INTRODUCTION}

The most challenging period in the lactation cycle of dairy cows occurs during the transition period from late gestation to early lactation. During this transition, cows experience various physiological and metabolic adaptations such as insulin resistance, reduced feed intake and immune function, and negative energy balance (NEB; Drackley, 1999). Negative energy balance results when energy requirements to sustain milk production during early lactation are not met by the energy intake (Herdt, 2000; McArt et al., 2013a). Cows undergoing NEB will experience increased lipolysis in fat stores and, consequently, increased production of nonesterified fatty acids (NEFA) that will be taken up by the liver.

Prolonged periods with high blood NEFA concentrations reaching the liver will eventually impair the 
ability of the liver to completely oxidize NEFA; this response is evidenced by increased blood ketone bodies (i.e., BHB, acetoacetate, and acetone), which are the product of partially oxidized NEFA. Cows experiencing high ketones levels $(>1.4 \mathrm{mmol} / \mathrm{L})$ in blood through the first $2 \mathrm{wk}$ after calving are potentially at risk of developing clinical ketosis and are at increased risk to develop other postpartal diseases such as displaced abomasum and metritis (LeBlanc, 2010; Seifi et al., 2011). This scenario is likely to result in lower conception rates at first service and lower milk production in early lactation, dampening the profitability of any dairy operation (McLaren et al., 2006).

Currently, prepartal blood NEFA concentration is one of the most reliable tools to predict which cows are at risk of developing postpartal diseases (Ospina et al., 2010; Chapinal et al., 2011); however, the ability to measure this biomarker in a dairy-farm setting is limited, not practical, and time consuming. After calving, one of the preferred tests for monitoring subclinical ketosis is the hand-held Precision Xtra (validated by Iwersen et al., 2009; Abbott Diabetes Care, Alameda, $\mathrm{CA}$ ), which measures blood BHB concentration. Unfortunately, the onset of ketosis can be either gradual or acute, depending on several conditions such BCS at calving, amount of NEFA mobilization, stress conditions, and inflammatory challenges (Trevisi et al., 2016). Therefore, parameters that can accurately predict whether cows are at risk of developing ketosis will give a significant advantage to dairy farmers.

Ketosis is a common postpartal disease in dairy cows, which is highly associated with liver function or the capacity of the liver to metabolize the surge of NEFA reaching the liver during the transition period. Thus, inflammatory conditions during the transition period of dairy cows have been commonly observed to impair liver function, and these conditions can considerably exacerbate metabolic disorders such as ketosis (Bertoni et al., 2008). The specific relationship between inflammation and ketosis has been investigated by Abuajamieh et al. (2016), where a consistent increase in inflammatory biomarkers (i.e., serum amyloid $\mathrm{A}$ and haptoglobin) and BHB was observed in ketotic cows. Therefore, it is conceivable that the increased synthesis and production of inflammatory biomarkers in the liver can diminish its functional capacity and render this organ unable to face the need to metabolize the excess NEFA and, consequently, increase ketone synthesis (Trevisi et al., 2012).

Prepartal behavioral patterns, such as standing and lying time budgets, of dairy cows monitored through sensor systems had shown promising results on predicting which cows are at risk of developing subclinical ketosis after calving (Goldhawk et al., 2009; Itle et al.,
2015; Kaufman et al., 2016b). In fact, sensor systems that record acceleration in the 3 axes (i.e., $\mathrm{X}, \mathrm{Y}$, and $\mathrm{Z}$ ) have been previously validated for recognition of various behavioral patterns in dairy cows (Ledgerwood et al., 2010), and similar sensor systems have already been implemented on commercial dairy farms. However, much still needs to be improved on the use of behavioral data derived from accelerometers to predict ketosis, for instance, combining these data with blood biomarker profiling related to aspects of inflammation, oxidative stress, and liver function. Indeed, little information currently exists on blood biomarkers and the physiological adaptations aforementioned during the onset of ketosis. Therefore, the objective of this study was to determine which behavioral patterns derived from accelerometer data, such as standing behavior and lying behavior, in peripartal dairy cows could allow early detection of subclinical ketosis during the days leading to the onset of this condition.

\section{MATERIALS AND METHODS}

\section{Experimental Design and Retrospective Analysis}

All the protocols for this study (protocol no. 12097) were approved by The Institutional Animal Care and Use Committee. Details for the original experimental design to test the effects of metal AA complexes fed to transition dairy cows have been published previously (Osorio et al., 2016). Briefly, 44 multiparous Holstein cows were enrolled at $110 \mathrm{~d}$ before calving and offered a common diet supplemented entirely with inorganic trace minerals to meet the requirements until $30 \mathrm{~d}$ before calving (NRC, 2001). From $30 \mathrm{~d}$ before calving, cows received a common prepartal diet $(1.5 \mathrm{Mcal} / \mathrm{kg}$ of DM, $15 \% \mathrm{CP}$ ), and from calving to $30 \mathrm{DIM}$ cows received a common postpartal diet $(1.76 \mathrm{Mcal} / \mathrm{kg}$ of DM, $18 \% \mathrm{CP}$ ). Both diets were partly supplemented with an inorganic trace mineral mix of $\mathrm{Zn}, \mathrm{Mn}$, and $\mathrm{Cu}$ to supply 35,45 , and $6 \mathrm{mg} / \mathrm{kg}$, respectively, of the total DM. The remaining trace mineral supplementation to achieve $75,65,11$, and $1 \mathrm{mg} / \mathrm{kg}$ of $\mathrm{Zn}, \mathrm{Mn}, \mathrm{Cu}$, and $\mathrm{Co}$, respectively, in the total DM was supplied via oral bolus from -30 to $30 \mathrm{~d}$ relative to parturition. Cows were fed individually once daily at $0630 \mathrm{~h}$ using an individual gate system (American Calan Inc., Northwood, NH). Cows were housed in a ventilated, enclosed barn during the dry period and had access to sand-bedded freestalls until 3 d before expected parturition, when they were moved until parturition to individual maternity pens bedded with straw. After parturition, cows were housed in a tiestall barn and fed a common lactation diet once daily. For the current study a subset of 24 cows was fitted with an accelerometer (HOBO pendant $\mathrm{G}$ logger; 
Onset Computer Corporation, Bourne, MA) mounted laterally to the distal left hind leg using vet wrap from -30 to $15 \mathrm{~d}$ relative to parturition. A retrospective analysis was performed in this subset of cows, using the postpartal BHB data measured at 8 time points with the Precision Xtra (Abbott Diabetes Care). Cows with an average $\mathrm{BHB}<1.4 \mathrm{mmol} / \mathrm{L}$ from 0 to $15 \mathrm{DIM}$ were designated nonketotic (NONKET; $\mathrm{n}=12$ ), and those cows with $\geq 1.4 \mathrm{mmol} / \mathrm{L}$ were designated ketotic $($ KET; $\mathrm{n}=12)$. On average $( \pm \mathrm{SD})$, NONKET cows had $7.4 \pm 0.5$ time points below the subclinical ketosis threshold $(1.4 \mathrm{mmol} / \mathrm{L})$, and KET cows had $6.2 \pm 1.8$ time points above the threshold. The threshold used in this study was based on previous observations by Oetzel and McGuirk (2008). Cows diagnosed with hyperketonemia were treated with propylene glycol. A total of 8 samples per cow were used for this analysis. Then, subsequent analyses of behavioral patterns and blood biomarkers were performed using this group effect.

\section{Behavioral Patterns}

Standing and lying behaviors were derived from accelerometer data as validated by Ledgerwood et al. (2010), and the activity monitor was set to record activity at a 60 -s interval. The backup data were used to analyze lying time, duration, and bouts (no./24 h) and duration of each bout, as well as standing time, duration, and bouts (no./24 h) and duration of each bout.

\section{Blood and Biomarker Analyses}

Blood samples were collected from the coccygeal vein before morning feeding into evacuated tubes (BD Vacutainer, BD and Co., Franklin Lakes, NJ) containing either clot activator or lithium heparin for serum and plasma, respectively. After blood collection, tubes with lithium heparin were placed on ice and tubes with clot activator were kept at $4^{\circ} \mathrm{C}$ until centrifugation $(\sim 30 \mathrm{~min})$. Serum and plasma were frozen $\left(-80^{\circ} \mathrm{C}\right)$ until further analysis. Specific details on the assays and procedures used to analyze the several blood biomarkers have been previously described (Batistel et al., 2016; Osorio et al., 2016). Briefly, blood samples were analyzed for biomarkers of metabolism (e.g., glucose, NEFA, creatinine, and urea), inflammation (e.g., ceruloplasmin, serum amyloid A, haptoglobin, IL-6, retinol, tocopherol, and $\beta$-carotene), liver function [e.g., albumin, bilirubin, glutamic-oxaloacetic transaminase (GOT), $\gamma$-glutamyltransferase (GGT), cholesterol, and paraoxonase $(\mathbf{P O N})]$, and oxidative stress [e.g., myeloperoxidase, reactive oxygen metabolites (ROM), nitric oxide $\left(\mathbf{N O}_{\mathbf{X}}\right)$, nitrite $\left(\mathrm{NO}_{2}^{-}\right)$, nitrate $\left(\mathrm{NO}_{3}{ }^{-}\right)$, and ferric reducing antioxidant power (FRAP)] using the IL Test purchased from Instrumentation Laboratory Spa (Werfen Co., Milan, Italy) in the ILAB 600 clinical auto-analyzer (Instrumentation Laboratory, Lexington, MA). Whole-blood concentration of BHB was measured via Precision Xtra every other day from 1 to $15 \mathrm{~d}$ postpartum; the assay suitability for accurately measuring blood ketones has been verified (Iwersen et al., 2009).

\section{Statistical Analysis}

Data for behavioral patterns, blood biomarkers, and performance parameters were analyzed with the PROC MIXED procedure of SAS 9.4 (SAS Institute Inc., Cary, $\mathrm{NC}$ ) according to the following model:

$$
Y_{i j k}=\mu+D_{i}+T_{j}+D T_{i j}+C_{k(i)}+e_{i j k},
$$

where $Y_{i j k}$ is the dependent, continuous variable; $\mu$ is the overall mean; $D_{i}$ is the fixed effect of the $i$ th group $(i=1$ and 2$) ; T_{j}$ is the fixed effect of the $j$ th time $(j$ $=1, \ldots, n) ; D T_{i j}$ is the fixed effect of the $i$ th group by the $j$ th time of the experiment interaction; $C_{k(i)}$ is the random effect of $k$ th cow within the $i$ th group; and $e_{i j k}$ is the residual error. In the model, the fixed effects included group (i.e., NONKET or KET), time, and their interaction (group $\times$ time; $\mathbf{G} \times \mathbf{T}$ ). Cow was considered the experimental unit and the random effect nested within group. For behavioral patterns and performance parameters, the autoregressive one covariance structure was used, which returned the lowest Akaike information criterion among all covariance structures tested. Unequally spaced data were analyzed using the exponential correlation covariance structure SP for repeated measures. For blood biomarkers, the data on d -30 relative to parturition were used as a covariate. Residual distribution was evaluated for normality and homoscedasticity. Statistical differences were declared significant at $P \leq 0.05$, and tendencies were discussed when $0.05 \leq P \leq 0.10$.

\section{RESULTS}

\section{Retrospective Analysis}

On average, whole blood BHB from cows evaluated in this subset group reached the threshold for subclinical ketosis $(1.4 \mathrm{mmol} / \mathrm{L})$ by $3 \mathrm{~d}$ postpartum and remained above this threshold for the entire evaluation period (Supplemental Figure S1; https://doi.org/10.3168/jds .2017-14254). This effect indicates a set of cows had a likelihood to undergo at least a constant subclinical ketosis condition. Therefore, the retrospective analysis based on blood BHB after calving was performed 


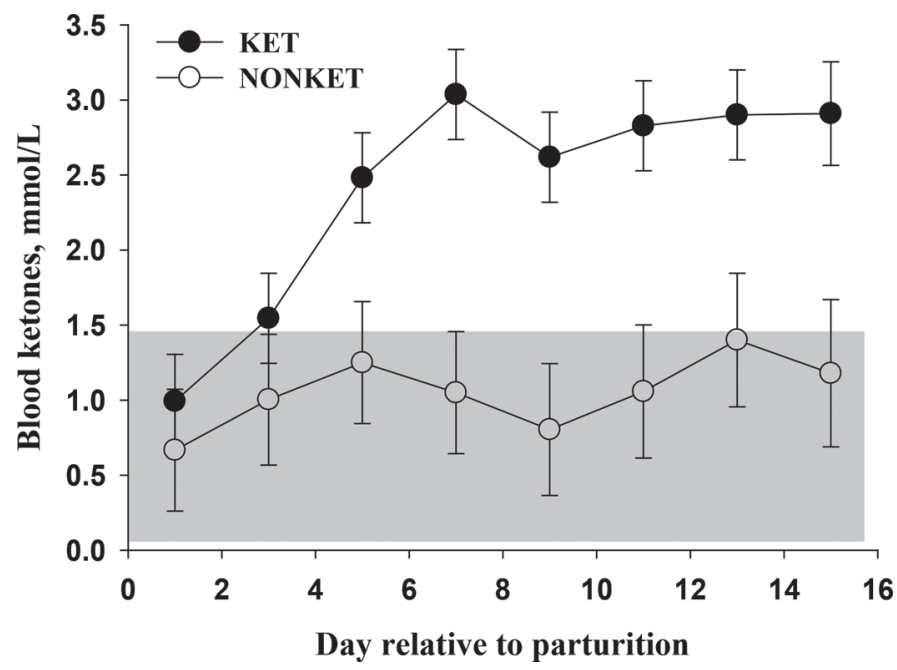

Figure 1. Retrospective analysis of blood ketones measured with Precision Xtra (Abbott Diabetes Care Inc., Alameda, CA) to derive a ketotic group (KET; $\geq 1.4 \mathrm{mmol} / \mathrm{L}$ ) and a nonketotic group (NONKET; $<1.4 \mathrm{mmol} / \mathrm{L}$ ) of dairy cows after calving. The gray area represents nonketotic conditions below the threshold of $1.4 \mathrm{mmol} / \mathrm{L}$ of BHB. Values are means, with standard errors represented by vertical bars.

to group cows with an average $\mathrm{BHB} \geq 1.4 \mathrm{mmol} / \mathrm{L}$ as KET or $<1.4 \mathrm{mmol} / \mathrm{L}$ as NONKET during the first 15 d postpartum (Figure 1).

\section{Behavioral Patterns}

The behaviors derived from the accelerometer data are presented in Table 1 . A trend $(P=0.10)$ existed for a $\mathrm{G} \times \mathrm{T}$ interaction for postpartal standing bouts. How- ever, this effect did not translate in a group effect $(P=$ 0.43 ) in postpartal standing bouts. The KET cows had lesser $(P=0.02)$ prepartal standing time and tended to have shorter $(P=0.06)$ prepartal standing duration and more $(P=0.10)$ prepartal standing bouts. In contrast to prepartal, postpartal behavior were less affected by group, with only a trend for KET cows to have more frequent $(P=0.02)$ postpartal lying bouts than NONKET. Although a $\mathrm{G} \times \mathrm{T}(P \geq 0.30)$ effect was not observed in standing time during the peripartal period, an increase in standing time was evident for NONKET cows in the days (i.e., -20 to 3 d relative to parturition) around parturition (Figure $2 \mathrm{~A}$ and $2 \mathrm{~B}$ ). Because of the prominent effect of group (KET vs. NONKET) on prepartal standing times (Table 1; Figure 2), a correlation analysis was performed between these behavior patterns (i.e., standing and lying time) from -30 to 3 d relative to parturition and blood BHB concentrations at 3 d postpartum (Figure 3 and Supplemental Figure S2; https://doi.org/10.3168/jds.2017-14254), when cows reached the threshold $(1.4 \mathrm{mmol} / \mathrm{L})$ for subclinical ketosis. Interestingly, the greatest absolute $(+$ or -$)$ correlation $(P<0.01 ; \mathrm{r}=-0.84)$ was obtained between standing time at $3 \mathrm{~d}$ before calving and blood BHB at 3 d postpartum (Figure 3 ).

\section{Milk Production, DMI, BW, and BCS}

The milk yield and quality, and performance parameters are presented in Table 2. A $\mathrm{G} \times \mathrm{T}$ effect $(P<$ 0.01 ) existed for milk yield, which resulted in NONKET cows producing $5.7 \mathrm{~kg} / \mathrm{d}$ more than KET cows

Table 1. Effects of postpartal ketosis on standing and lying behaviors of cows during the peripartal period

\begin{tabular}{|c|c|c|c|c|c|c|}
\hline \multirow[b]{2}{*}{ Parameter } & \multicolumn{2}{|c|}{ Group $^{1}$} & \multirow[b]{2}{*}{$\mathrm{SEM}^{2}$} & \multicolumn{3}{|c|}{$P$-value } \\
\hline & KET & NONKET & & Group (G) & Time $(\mathrm{T})^{3}$ & $\mathrm{G} \times \mathrm{T}$ \\
\hline \multicolumn{7}{|l|}{ Prepartum } \\
\hline Standing time, min & 625.2 & 770.4 & 42.27 & 0.02 & 0.70 & 0.30 \\
\hline Standing duration, ${ }^{4}$ min & 74.4 & 110.1 & 0.21 & 0.06 & 0.56 & 0.16 \\
\hline Standing bouts, ${ }^{4}$ no. & 8.7 & 6.8 & 0.15 & 0.10 & 0.26 & 0.15 \\
\hline Lying time, min & 814.8 & 669.6 & 42.3 & 0.02 & 0.70 & 0.30 \\
\hline Lying duration, ${ }^{4} \min$ & 65.0 & 66.2 & 0.17 & 0.91 & 0.25 & 0.56 \\
\hline Lying bouts, ${ }^{4}$ no. & 11.5 & 10.1 & 0.16 & 0.41 & 0.49 & 0.66 \\
\hline \multicolumn{7}{|l|}{ Postpartum } \\
\hline Standing time, $\min$ & 796.3 & 889.5 & 61.7 & 0.25 & 0.06 & 0.38 \\
\hline Standing duration, min & 71.7 & 102.5 & 0.24 & 0.11 & 0.40 & 0.61 \\
\hline Standing bouts, no. $/ 24 \mathrm{~h}$ & 11.9 & 10.2 & 1.64 & 0.43 & $<0.01$ & 0.10 \\
\hline Lying time, min & 643.7 & 550.5 & 61.7 & 0.25 & 0.06 & 0.38 \\
\hline Lying duration, min & 47.3 & 44.4 & 6.70 & 0.84 & $<0.01$ & 0.11 \\
\hline Lying bouts, no. & 12.9 & 9.3 & 1.35 & 0.06 & $<0.01$ & 0.78 \\
\hline
\end{tabular}

${ }^{1} \mathrm{KET}=$ ketotic, cows with an average $\mathrm{BHB} \geq 1.4 \mathrm{mmol} / \mathrm{L}$ from 0 to 15 DIM; NONKET $=$ nonketotic, cows with an average $\mathrm{BHB}<1.4 \mathrm{mmol} / \mathrm{L}$ from 0 to 15 DIM.

${ }^{2}$ Largest SEM is shown.

${ }^{3}$ Data were analyzed as daily behavioral patterns.

${ }^{4}$ Data were log-transformed before statistics were generated. 

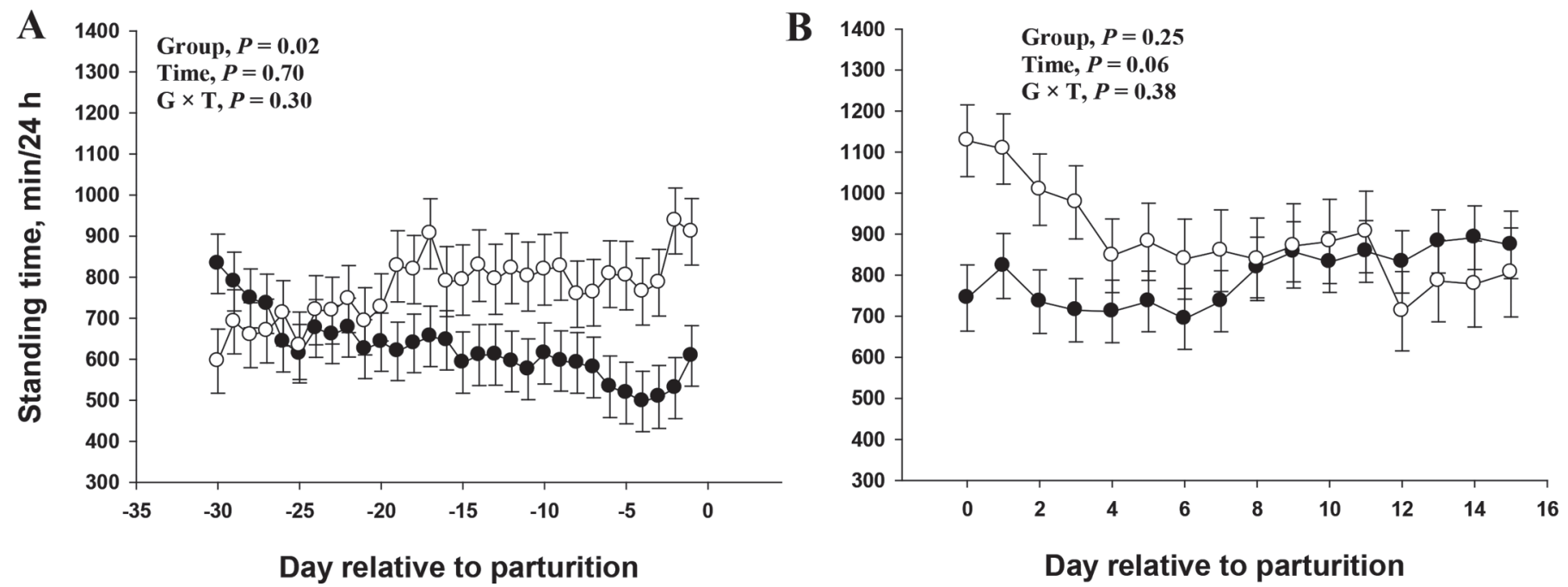

Figure 2. Effect of postpartal ketosis on prepartal (A) and postpartal (B) standing time (min/24 h) behaviors of peripartal dairy cows. Values are means, with standard errors represented by vertical bars. KET $=$ ketotic, cows with an average BHB $\geq 1.4 \mathrm{mmol} / \mathrm{L}$ from 0 to $15 \mathrm{DIM}$; NONKET $=$ nonketotic, cows with an average $\mathrm{BHB}<1.4 \mathrm{mmol} / \mathrm{L}$ from 0 to $15 \mathrm{DIM} ; \mathrm{G}=$ group; $\mathrm{T}=$ time .

(Figure 4). A group effect $(P<0.01)$ existed for DMI, where KET cows consumed almost $3 \mathrm{~kg}$ of DM/d less than the NONKET cows, primarily during the days around parturition (Figure 4). Milk protein content was only affected $(P<0.01)$ by time, and BCS and milk fat content were not affected $(P \geq 0.25)$ by experimental effects.

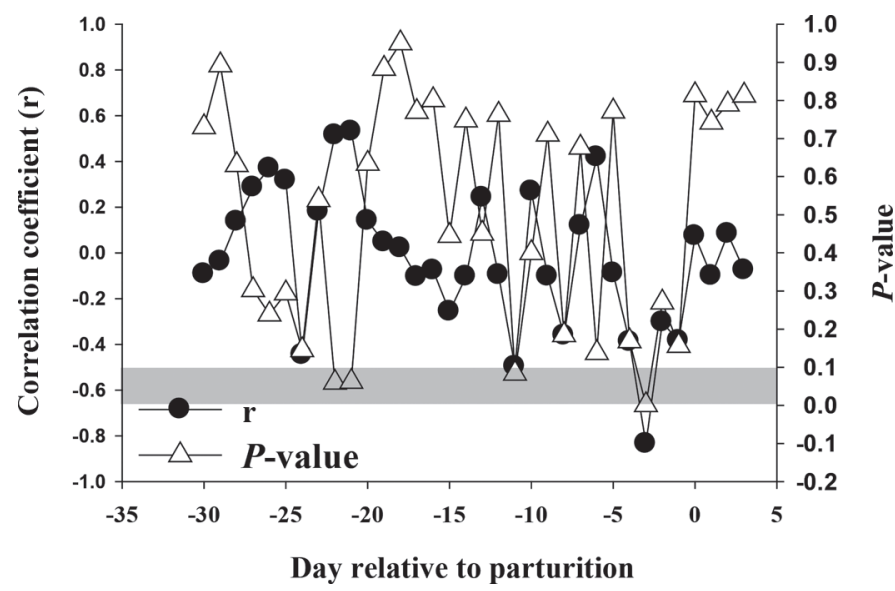

Figure 3. Correlation analysis of standing time behavior from -30 to $3 \mathrm{~d}$ relative to parturition to blood ketone concentration at $3 \mathrm{~d}$ after calving in peripartal dairy cows. Black circles represent the correlation coefficient ( $\mathrm{r}$ ) for a specific time point, and the white triangles represent the $P$-value associated with such $\mathrm{r}$. The gray area indicates time points for which at least a trend $(P \leq 0.10)$ for significance on the correlation was observed.

\section{Blood Biomarkers}

Main effects for blood biomarkers are presented in Table 3. We looked at energy-related metabolites, and biomarkers of inflammation, liver function, and oxidative stress.

Energy-Related Metabolites. A G $\times$ T interaction existed for creatinine $(P=0.01)$ and NEFA $(P=0.01$; Table 3$)$. The $\mathrm{G} \times \mathrm{T}$ interaction observed in creatinine was associated with greater concentration of creatinine in NONKET cows than in KET at 15 and 30 d relative to parturition. Therefore, an overall greater $(P=0.05)$ concentration of creatinine was observed in NONKET cows in comparison with KET. In contrast to creatinine, the $\mathrm{G} \times \mathrm{T}$ interaction in NEFA was reflected in a lower concentration in NONKET cows than in KET at $-14 \mathrm{~d}$ relative to parturition (Figure 5 ). The trend for $\mathrm{G} \times \mathrm{T}$ in urea $(P=0.07)$ was associated with a time effect $(P<0.01)$ but not with a group effect $(P=0.70)$. As expected, based on the group separation mentioned above, BHB concentration was greater $(P<0.01)$ in KET cows than in NONKET (2.23 vs. $0.99 \mathrm{mmol} / \mathrm{L}$ ).

Biomarkers of Inflammation. The $\mathrm{G} \times \mathrm{T}$ interaction $(P=0.02)$ in IL-6 was associated with a greater $(P=0.03)$ concentration in NONKET cows than in KET at $-14 \mathrm{~d}$ relative to parturition (Figure 6). Although overall postpartal IL-6 between KET and NONKET cows did not reach statistical significance $(P$ $=0.11$ ), a more pronounced reduction (63 vs. $91 \%$ ) in IL-6 from prepartum to postpartum was observed in 
Table 2. Effects of postpartal ketosis on DMI, BW, BCS, and production parameters of peripartal dairy cows

\begin{tabular}{|c|c|c|c|c|c|c|}
\hline \multirow[b]{2}{*}{ Parameter } & \multicolumn{2}{|c|}{ Group $^{1}$} & \multirow[b]{2}{*}{$\mathrm{SEM}^{2}$} & \multicolumn{3}{|c|}{$P$-value } \\
\hline & KET & NONKET & & Group (G) & Time $(\mathrm{T})$ & $\mathrm{G} \times \mathrm{T}$ \\
\hline$\overline{\mathrm{DMI}}{ }^{3} \mathrm{~kg} / \mathrm{d}$ & 11.81 & 14.8 & 0.75 & $<0.01$ & 0.11 & 0.81 \\
\hline $\mathrm{BW},{ }^{4} \mathrm{~kg}$ & 732.9 & 778.6 & 38.7 & 0.36 & $<0.01$ & 0.13 \\
\hline $\mathrm{BCS}^{4}$ & 3.4 & 3.3 & 0.15 & 0.59 & 0.82 & 0.36 \\
\hline Milk yield,${ }^{5} \mathrm{~kg} / \mathrm{d}$ & 32.41 & 38.1 & 3.09 & 0.15 & $<0.01$ & $<0.01$ \\
\hline Milk fat, ${ }^{6} \%$ & 5.2 & 5.4 & 0.54 & 0.81 & 0.25 & 0.98 \\
\hline Milk protein, ${ }^{6} \%$ & 3.4 & 3.5 & 0.19 & 0.68 & $<0.01$ & 0.36 \\
\hline \multicolumn{7}{|c|}{$\begin{array}{l}{ }^{1} \mathrm{KET}=\text { ketotic, cows with an average } \mathrm{BHB} \geq 1.4 \mathrm{mmol} / \mathrm{L} \text { from } 0 \text { to } 15 \mathrm{DIM} \text {; NONKET }=\text { nonketotic, con } \\
\text { with an average } \mathrm{BHB}<1.4 \mathrm{mmol} / \mathrm{L} \text { from } 0 \text { to } 15 \mathrm{DIM} \text {. }\end{array}$} \\
\hline \multicolumn{7}{|c|}{${ }^{2}$ Largest SEM is shown. } \\
\hline \multicolumn{7}{|c|}{${ }^{3} \mathrm{DMI}$ analyzed from -15 to $3 \mathrm{~d}$ relative to parturition. } \\
\hline \multicolumn{7}{|c|}{${ }^{4} \mathrm{BW}$ and $\mathrm{BCS}$ analyzed from -2 to 1 wk relative to parturition. } \\
\hline \multicolumn{7}{|c|}{${ }^{5}$ Milk yield analyzed from 1 to $15 \mathrm{~d}$ after calving. } \\
\hline${ }^{6}$ Milk fat and prot & f & & & & & \\
\hline
\end{tabular}

NONKET cows than in KET (Figure 6). A trend $(P=$ 0.06 ) for a $\mathrm{G} \times \mathrm{T}$ interaction was observed in retinol, which was associated with a greater $(P<0.01)$ retinol concentration in NONKET cows than in KET at $3 \mathrm{~d}$ postpartum (Figure 6). Overall tocopherol concentration was greater $(P=0.02)$ in NONKET cows than in KET. Ceruloplasmin, haptoglobin, serum amyloid $\mathrm{A}$, and $\beta$-carotene concentrations were only affected by time $(P<0.02)$.

Liver Function. Among all the biomarkers related to liver function, GGT showed $(P=0.03)$ a $\mathrm{G} \times \mathrm{T}$ interaction (Table 3 ). The $\mathrm{G} \times \mathrm{T}$ interaction in GGT was associated with a trend $(P=0.08)$ for lesser GGT concentrations in NONKET cows than in KET at $30 \mathrm{~d}$ postpartum (Figure 6). Similarly to GGT, GOT tend $(P=0.09)$ to be lesser in NONKET cows than in KET. Overall bilirubin was lesser $(P=0.02)$ in NONKET cows than in KET, and a trend $(P=0.08)$ was observed in PON for greater PON concentration in NONKET cows than in KET. Cholesterol was only affected by time $(P<0.01)$, and albumin was not affected $(P \geq$ 0.15 ) by experimental effects (Table 3 ).

Oxidative Stress. A greater $(P=0.02)$ overall concentration of $\mathrm{NO}_{3}$ and FRAP was observed in KET cows in comparison with NONKET. Similar to $\mathrm{NO}_{3}$ and FRAP, a trend for greater $\mathrm{NO}_{\mathrm{X}}(P=0.09)$ and $\mathrm{NO}_{2}(P=0.08)$ was detected in KET cows in comparison with NONKET. Neither myeloperoxidase nor ROM was affected by the ketosis effect.

\section{DISCUSSION}

During the transition period, cows will normally experience NEB, which is characterized by lipid mobilization in the form of NEFA from adipose tissue to the liver, where NEFA are finally used as an en- ergy source to cope with the energy demands for milk production (Contreras and Sordillo, 2011). Ketosis is commonly associated with excessive NEFA infiltrating the liver, resulting in greater ketone bodies synthesis (e.g., BHB) because of partial $\beta$-oxidation of NEFA. Using electronic hand-held devices to measure BHB in blood has been proven to be a reliable method to detect clinical and subclinical ketosis in dairy cows (Iwersen et al., 2009; McArt et al., 2013b). Alternative methods such as sensor systems (i.e., accelerometers) for early detection of peripartal cows at risk of developing ketosis have been previously evaluated (Itle et al., 2015). However, further research is needed to construct clear links among accelerometer data, behavioral patterns, and BHB concentrations during early postpartum. The latter is under the hypothesis that accelerometer data can be a useful tool to detect cows at risk of developing clinical or even subclinical ketosis.

\section{Behavioral Patterns and DMI}

Behavioral patterns have been reported previously by monitoring cows activity or 3-dimensional movements with electronic devices such as pedometers (Kamphuis et al., 2013) and accelerometers, respectively (Ledgerwood et al., 2010). Peripartal behaviors such as cow displacement at the feed bunk and rumination measured using nonattached (i.e., video recording) and attached (i.e., collar microphone) devices, respectively, have been associated with feed intake and subclinical ketosis (Goldhawk et al., 2009; Soriani et al., 2012; Calamari et al., 2014; Kaufman et al., 2016a). Behavioral patterns measured through accelerometer data, such as the lying time during a 24 -h period, have been observed to decrease in the days around parturition, and this behavior was more pronounced with multiparous cows 
with subclinical ketosis than with healthy multiparous cows (Kaufman et al., 2016b).

Accelerometer data can account for behavioral changes that otherwise are impossible for dairy producers to observe on an individual-cow basis, especially in large dairy herds, and it is even more difficult to correlate behavioral data with cows at risk of developing peripartal diseases. Previously, a retrospective analysis combining accelerometer data and blood BHB measured with a hand-held device (i.e., Precision Xtra) in peripartal dairy cows reported that cows diagnosed with clinical ketosis postpartum had greater prepartal standing time during the week before calving (Itle et al., 2015).

Itle et al. (2015) reported that cows enduring ketosis postpartum stood longer the week before calving and also on the day of calving compared with the cows that did not develop the disease, and this behavior was associated with competition of ketotic cows for access to the feed bunks. In contrast to that study, our results indicate that standing time was remarkably less for KET cows in the days leading to calving, specifically from $6 \mathrm{~d}$ prepartum and maintaining that behavior during the first week postpartum (Figure 2). These results in KET cows can be associated with greater lying time (Supplemental Figure S3; https://doi.org/10.3168/jds .2017-14254), less time at the feed bunk, and, consequently, less DMI around calving time (Figure 4). In fact, ketosis in dairy cows has been associated with up to $26 \%$ reductions in DMI (Abuajamieh et al., 2016), and this agrees with our results, where KET cows had an evident reduction in DMI from $6 \mathrm{~d}$ before calving. These results are consistent with those reported by Goldhawk et al. (2009) and Kaufman et al. (2016b), where an association between increased lying behavior and predisposition to develop subclinical ketosis was reflected in a decrease in visits to the feed bunk and, consequently, decreased DMI.

The results in the current study contrast with those observed by Itle et al. (2015), and one of the main reasons for this effect was associated with a lack of traffic or competition observed to the feeding area prepartum. In our experiment, cows were switched to a tiestall barn after calving, and a continuous greater standing behavior in NONKET was observed (Figure 2) from prepartum (freestalls) to postpartum (tiestalls), suggesting that this change in housing system had a minimal effect on the behavior. A major limitation for the above comparison is the missing DMI data in the study by Itle et al. (2015); it is inconclusive whether the greater prepartal standing they observed was limiting DMI. Future experiments in this area should account for prepartal standing time without eating, which will directly reflect
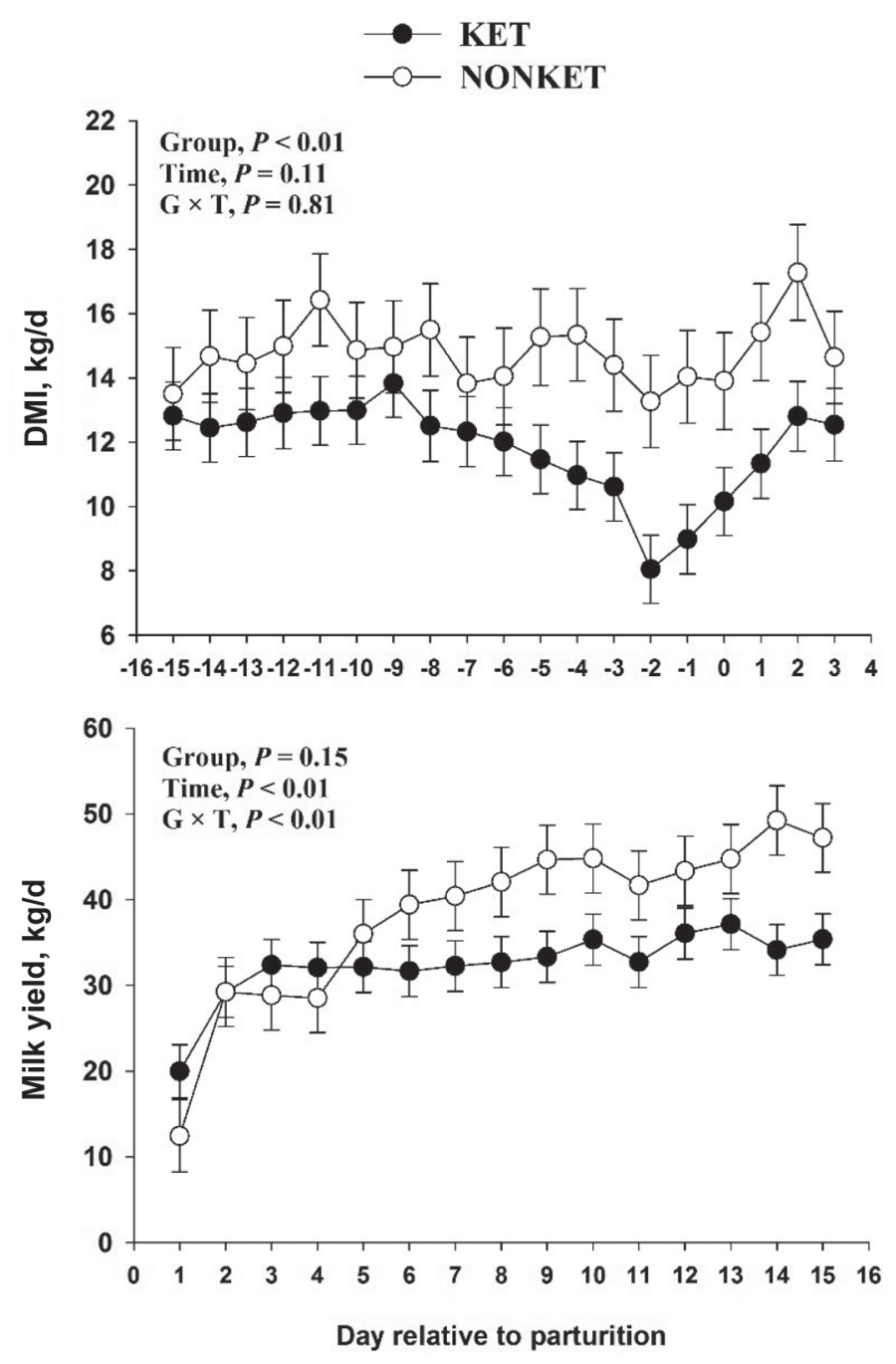

Figure 4. Effects of postpartal ketosis on DMI and milk yield of peripartal dairy cows. Values are means, with standard errors represented by vertical bars. KET = ketotic, cows with an average BHB $\geq 1.4 \mathrm{mmol} / \mathrm{L}$ from 0 to $15 \mathrm{DIM}$; NONKET = nonketotic, cows with an average $\mathrm{BHB}<1.4 \mathrm{mmol} / \mathrm{L}$ from 0 to $15 \mathrm{DIM} ; \mathrm{G}=$ group; $\mathrm{T}=$ time.

an overcrowding or poor bedding problem in dry cow barns, which can lead to ketosis postpartum.

Similar to our results, Edwards and Tozer (2004) observed that cows diagnosed with ketosis had lower walking activity after calving than did healthy cows, which was associated with cows having decreased appetite and spending less time at the feed bunk and more time lying down. Also, a decreased in rumination has also been associated with high ketone bodies (Soriani et al., 2012; Calamari et al., 2014). This same pattern has been previously reported in dairy cows with subclinical ketosis postpartum (Susenbeth et al., 2004; Weary et al., 2009). 
Table 3. Effects of postpartal ketosis on energy-related metabolites and biomarkers of inflammation and liver function of peripartal dairy cows

\begin{tabular}{|c|c|c|c|c|c|c|}
\hline \multirow[b]{2}{*}{ Parameter $^{1}$} & \multicolumn{2}{|c|}{ Group $^{2}$} & \multirow[b]{2}{*}{$\mathrm{SEM}^{3}$} & \multicolumn{3}{|c|}{$P$-value } \\
\hline & KET & NONKET & & Group (G) & Time $(\mathrm{T})$ & $\mathrm{G} \times \mathrm{T}$ \\
\hline \multicolumn{7}{|l|}{ Metabolism } \\
\hline $\mathrm{BHB},{ }^{4} \mathrm{mmol} / \mathrm{L}$ & 2.23 & 0.99 & 0.26 & $<0.01$ & 0.01 & 0.24 \\
\hline Glucose, $\mathrm{mmol} / \mathrm{L}$ & 3.66 & 3.58 & 0.14 & 0.63 & $<0.01$ & 0.31 \\
\hline $\mathrm{NEFA},{ }^{5} \mathrm{mmol} / \mathrm{L}$ & 0.42 & 0.36 & 0.13 & 0.15 & $<0.01$ & 0.01 \\
\hline Creatinine, $\mu \mathrm{mol} / \mathrm{L}$ & 85.20 & 93.07 & 2.64 & 0.05 & $<0.01$ & 0.01 \\
\hline Urea, $\mu \mathrm{mol} / \mathrm{L}$ & 5.38 & 5.76 & 0.74 & 0.70 & $<0.01$ & 0.07 \\
\hline \multicolumn{7}{|l|}{ Inflammation } \\
\hline Ceruloplasmin, $\mu \mathrm{mol} / \mathrm{L}$ & 3.54 & 3.91 & 0.32 & 0.41 & 0.02 & 0.80 \\
\hline $\mathrm{SAA}^{5}{ }^{5} \mu \mathrm{mol} / \mathrm{mL}$ & 60.97 & 51.62 & 0.57 & 0.74 & $<0.01$ & 0.59 \\
\hline Haptoglobin, ${ }^{5} \mathrm{~g} / \mathrm{L}$ & 0.38 & 0.43 & 0.29 & 0.58 & $<0.01$ & 0.92 \\
\hline $\mathrm{IL}-6, \mathrm{pg} / \mathrm{mL}$ & 527.3 & 472.1 & 131.3 & 0.74 & $<0.01$ & 0.02 \\
\hline Retinol, ${ }^{5} \mu \mathrm{g} / 100 \mathrm{~mL}$ & 24.42 & 36.50 & 0.26 & 0.11 & $<0.01$ & 0.06 \\
\hline Tocopherol, $\mu \mathrm{g} / 100 \mathrm{~mL}$ & 4.15 & 4.95 & 0.24 & 0.02 & $<0.01$ & 0.84 \\
\hline$\beta$-Carotene, $\mu \mathrm{g} / 100 \mathrm{~mL}$ & 0.19 & 0.19 & 0.02 & 0.90 & $<0.01$ & 0.95 \\
\hline \multicolumn{7}{|l|}{ Liver function } \\
\hline Albumin, g/L & 35.49 & 35.31 & 1.04 & 0.90 & 0.15 & 0.43 \\
\hline Bilirubin, $\mu \mathrm{mol} / \mathrm{L}$ & 3.42 & 2.89 & 0.17 & 0.02 & $<0.01$ & 0.41 \\
\hline $\mathrm{GGT},{ }^{5} \mathrm{U} / \mathrm{L}$ & 29.04 & 28.64 & 0.12 & 0.90 & $<0.01$ & 0.03 \\
\hline GOT, U/L & 111.9 & 96.5 & 6.9 & 0.09 & $<0.01$ & 0.11 \\
\hline Cholesterol, $\mathrm{mmol} / \mathrm{L}$ & 3.89 & 4.01 & 0.49 & 0.84 & $<0.01$ & 0.83 \\
\hline $\mathrm{PON},{ }^{5} \mathrm{U} / \mathrm{mL}$ & 82.71 & 99.04 & 0.11 & 0.08 & 0.15 & 0.52 \\
\hline \multicolumn{7}{|l|}{ Oxidative stress } \\
\hline $\mathrm{MPO}, \mathrm{U} / \mathrm{L}$ & 391.6 & 444.3 & 45.2 & 0.37 & 0.04 & 0.16 \\
\hline $\mathrm{ROM}, \mathrm{mg}$ of $\mathrm{H}_{2} \mathrm{O}_{2} / 100 \mathrm{~mL}$ & 12.29 & 14.15 & 1.06 & 0.20 & 0.10 & 0.93 \\
\hline $\mathrm{NO}_{\mathrm{x}}, \mu \mathrm{mol} / \mathrm{L}$ & 12.04 & 10.86 & 0.54 & 0.09 & 0.05 & 0.99 \\
\hline $\mathrm{NO}_{2}, \mu \mathrm{mol} / \mathrm{L}$ & 5.80 & 4.97 & 0.39 & 0.08 & 0.22 & 0.79 \\
\hline $\mathrm{NO}_{3}, \mu \mathrm{mol} / \mathrm{L}$ & 6.12 & 5.24 & 0.29 & 0.02 & 0.61 & 0.47 \\
\hline $\mathrm{FRAP}, \mu \mathrm{mol} / \mathrm{L}$ & 141.7 & 110.4 & 9.2 & 0.02 & 0.07 & 0.91 \\
\hline
\end{tabular}

${ }^{1}$ Metabolites and biomarkers were analyzed from -30 to 3 d relative to parturition. NEFA $=$ nonesterified fatty acid; SAA $=$ serum amyloid A; GTT $=\gamma$-glutamyltransferase; GOT = glutamic-oxaloacetic transaminase; $\mathrm{PON}=$ paraoxonase $\mathrm{MPO}=$ myeloperoxidase $; \mathrm{ROM}=$ reactive oxygen metabolites; $\mathrm{NO}_{\mathrm{x}}=$ nitric oxide; $\mathrm{NO}_{2}$ $=$ nitrite $; \mathrm{NO}_{3}=$ nitrate; FRAP $=$ ferric reducing antioxidant power.

${ }^{2} \mathrm{KET}=$ ketotic, cows with an average $\mathrm{BHB} \geq 1.4 \mathrm{mmol} / \mathrm{L}$ from 0 to $15 \mathrm{DIM}$; NONKET $=$ nonketotic, cows with an average BHB $<1.4 \mathrm{mmol} / \mathrm{L}$ from 0 to 15 DIM.

${ }^{3}$ Largest SEM is shown.

${ }^{4}$ Measured using the Precision Xtra (Abbott Diabetes Care Inc., Alameda, CA).

${ }^{5}$ Data were log-transformed before statistics were generated. Back-transformed least squares means data are shown, and the associated SEM remained as log-scale.

\section{Milk Production}

The effect of ketosis on milk production has been previously observed by Abuajamieh et al. (2016), where a decrease of 10.3 or $3.2 \mathrm{~kg} / \mathrm{d}$ in milk production was reported in 2 independent retrospective studies. Similar to in the study by Abuajamieh et al. (2016), a decrease of $5.7 \mathrm{~kg} / \mathrm{d}$ in milk production was observed in KET cows in comparison with NONKET cows.

\section{Biomarkers of Metabolism}

During the transition period, dairy cows experience a deficit in nutrient supply, primarily due to the decreased in DMI around parturition. This scenario not only leads to a common state of NEB but also leads to a negative protein balance, which is characterized by a significant mobilization of tissue protein to meet mammary and extramammary AA requirements for important biological processes such as hepatic gluconeogenesis (Bell et al., 2000). Within this context, creatinine is an important biomarker, because it indicates body muscle mass and its concentration typically decreases around parturition (Kokkonen et al., 2005). Accordingly, our results show that KET cows were under negative protein balance, which is confirmed by the evident postpartal decrease in creatinine in KET cows and suggests that these cows were mobilizing greater amounts of tissue protein than were NONKET cows.

High prepartum NEFA has been associated with an increased predisposition to develop ketosis and other diseases after calving (Ospina et al., 2010; McArt et al., 2013b). Similarly, our data indicate that greater prepartum NEFA concentration (Figure 5) in KET 

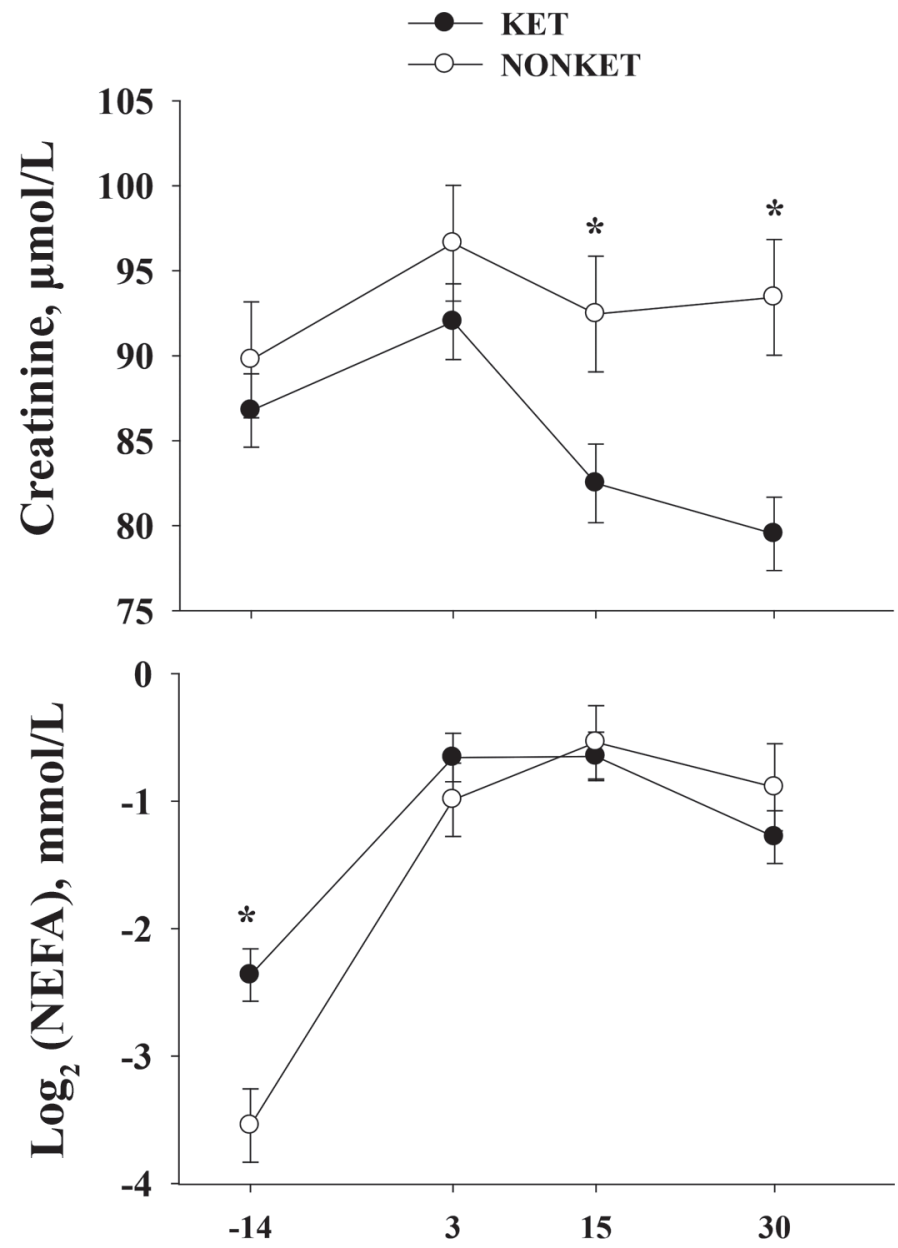

\section{Day relative to parturition}

Figure 5. Effect of postpartal ketosis on metabolic biomarkers, creatinine and nonesterified fatty acids (NEFA), in peripartal dairy cows. Mean separation between groups at a given time point was evaluated when a group $\times$ time effect $(P \leq 0.10)$ was observed. Differences $\left(^{*}\right)$ were declared at $P \leq 0.05$. Values are means, with standard errors represented by vertical bars. KET = ketotic, cows with an average BHB $\geq 1.4 \mathrm{mmol} / \mathrm{L}$ from 0 to $15 \mathrm{DIM}$; NONKET $=$ nonketotic, cows with an average $\mathrm{BHB}<1.4 \mathrm{mmol} / \mathrm{L}$ from 0 to 15 DIM.

cows was associated with their eventual development of ketosis postpartum.

\section{Biomarkers of Inflammation}

The peripartal period for dairy cows is often characterized by undergoing an inflammatory condition (Bionaz et al., 2007; Loor et al., 2013), which is commonly associated with a dysregulation of the normal hepatic synthesis of proteins, the acute phase response (Bertoni et al., 2008). Among the biomarkers for inflammatory response, IL-6 has been commonly used in peripartal dairy cows (Trevisi et al., 2012; Batistel et al., 2016)
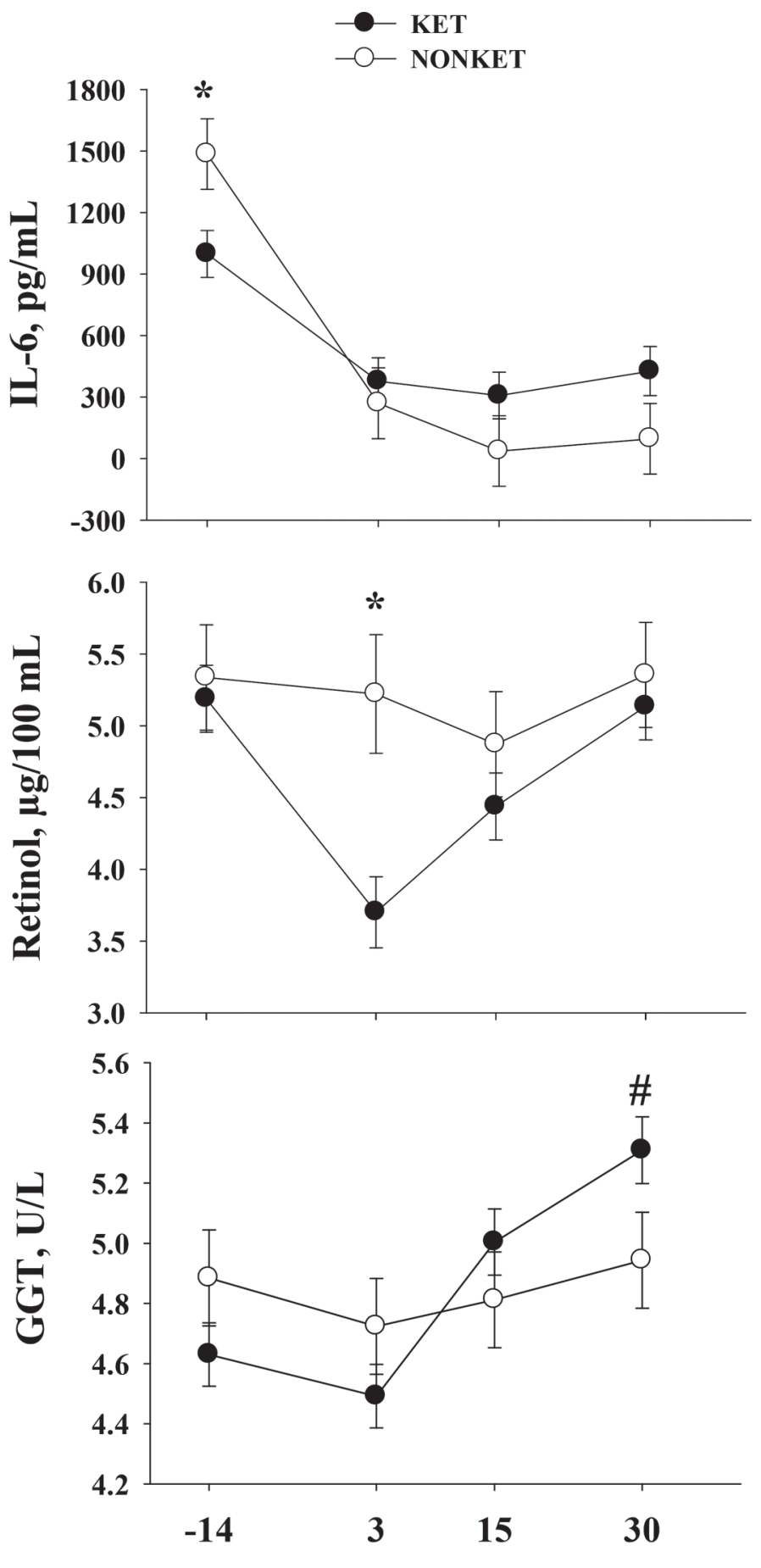

\section{Days relative to parturition}

Figure 6. Effect of postpartal ketosis on biomarkers of inflammation (i.e., IL-6 and retinol) and liver function [i.e., $\gamma$-glutamyltransferase (GGT)] in peripartal dairy cows. Mean separation between groups at a given time point was evaluated when a group $\times$ time effect $(P \leq 0.15)$ was observed. Differences $(*)$ were declared at $P \leq 0.05$, and tendencies (\#) were declared at $P \leq 0.10$. Values are means, with standard errors represented by vertical bars. KET $=$ ketotic, cows with an average $\mathrm{BHB} \geq 1.4 \mathrm{mmol} / \mathrm{L}$ from 0 to $15 \mathrm{DIM}$; NONKET $=$ nonketotic, cows with an average BHB $<1.4 \mathrm{mmol} / \mathrm{L}$ from 0 to 15 DIM. 
because it is a proinflammatory cytokine responsible for hepatic regulation of acute phase protein synthesis. In fact, Trevisi et al. (2012) observed that cows with low liver function (i.e., high inflammatory condition) during early lactation had a significant increase in IL-6 (>300 pg/mL). Similarly, in our study, we observed that KET cows had an IL-6 concentration surpassing $300 \mathrm{pg} / \mathrm{mL}$ (Figure 6), which indicates these cows were under an inflammatory condition, likely due to the subclinical ketosis. The prepartal inflammatory condition, based on IL-6, was less clear because the levels for this biomarker were markedly higher in both groups in comparison with other studies (Trevisi et al., 2015), which suggests that other factors contribute to the inflammatory status and, thus, to the basal level of IL-6. However, the latter does not diminish the evident postpartal reduction of IL-6 in NONKET cows, suggesting a more favorable status (i.e., less inflammation and less ketogenesis) in early lactation.

In rodents, vitamin concentrations such as tocopherol and retinol can be reduced in tissues (i.e., lung, liver, and heart) and plasma by inflammatory conditions (Henning et al., 1997). In the context of transition dairy cows, a decreased in blood retinol has been partially associated with the transfer of retinol and its derivatives into colostrum (Goff et al., 2002). Also, inflammation during this period (Schweigert, 2001; Bionaz et al., 2007) reduces the synthesis of retinol binding protein (Bertoni et al., 2008). Therefore, the lower retinol concentration in KET cows at $3 \mathrm{~d}$ postpartum along with the overall lesser tocopherol in KET cows underscores an inflammatory condition in this group of cows.

\section{Biomarkers of Liver Function}

The inflammatory response is often evaluated through a blood profile of biomarkers, particularly those related to liver function, which has been closely associated with health and welfare in dairy cows (Bertoni et al., 2008). This is mainly associated with the key roles of the liver during the peripartal period, such as gluconeogenesis from AA and long-chain fatty acid metabolism (Drackley, 1999). Extensive inflammatory response coupled with fatty acid oxidation leads to a dysregulation of liver functions and, consequently, liver damage that its detrimental to health and welfare of peripartal dairy cows (Loor et al., 2013). Enzymes related to AA metabolism such as GGT and GOT have been commonly used as biomarkers of liver damage across species (Bertoni et al., 2008; Oh et al., 2011), and an increase in blood concentration of these enzymes is associated with liver damage. Therefore, the overall increase in GOT in KET cows and the increase in GGT at $30 \mathrm{~d}$ postpartum (Figure 6) indicate a significant degree of liver damage in these cows. A reduction in PON synthesis has been observed during liver damage or impaired function (Bionaz et al., 2007). Therefore, the trend $(P=0.08)$ for greater PON in NONKET cows also confirms that ketosis impairs liver function and, consequently, reduces the protection of lipoproteins during oxidative stress. Although bilirubin is not a protein per se, its clearance in blood is partially due to liver enzymes (Bertoni and Trevisi, 2013), therefore, the lesser bilirubin in NONKET cows further confirms a greater liver function in this group of cows.

\section{Biomarkers of Oxidative Stress}

Although the accumulation of free radicals in blood as observed via ROM was not affected by the effects of ketosis during the peripartal period, nitric oxide and its derivates $\mathrm{NO}_{2}$ and $\mathrm{NO}_{3}$ consistently increased in KET cows. The latter could be associated with nitric oxide and its derivates not being directly related to ROM, and the increased concentration of these metabolites can be further associated with inflammation (Sharma et al., 2007). Interestingly, recent work on nonmammalian subjects such as Zebrafish suggests that $\mathrm{NO}_{\mathrm{X}}$ plays a role in nonalcoholic fatty liver disease because it is essential for hepatic lipid metabolism during starvation (Gu et al., 2014). Taken together, it is a strong indicator that increased oxidation of fatty acids during a ketotic state in KET cows led to the increase of $\mathrm{NO}_{\mathrm{X}}$ and derivates (i.e., $\mathrm{NO}_{2}$ and $\mathrm{NO}_{3}$ ), and, as a consequence, the greater FRAP concentration in KET cow can be seen as a coping mechanism (Jacometo et al., 2015).

\section{Behavioral Patterns and Biomarkers}

Much is still left to be learned and new applications could be developed regarding the use of precision livestock farming devices such as accelerometers. In fact, in a recent review, Rutten et al. (2013) observed that sensor systems have been used in dairy cows to detect of mastitis, fertility, and locomotion problems, accounting for 25,33 , and $30 \%$, respectively, and to a lesser extent (i.e., $12 \%$ ) to study and detect metabolic problems. The latter underscores the importance of the current study, where the aim was to integrate sensor systems data and blood BHB to predict subclinical ketosis in early lactation cows. The uniqueness of the current data relies on the use of additional performance (e.g., DMI) and blood biomarkers of health and welfare to further confirm and detect physiological alterations caused by subclinical and clinical ketosis events in early-lactation cows. The correlation data in Figure 3 show the potential for observing strong correlations $(P<0.01 ; \mathrm{r}=-0.84)$ between behavioral patterns such as standing time dur- 
ing the last week ( $6 \mathrm{~d})$ before calving and blood BHB concentrations at $3 \mathrm{~d}$ postpartum, when overall $\mathrm{BHB}$ reached subclinical levels. The behavioral and biological link between these parameters was confirmed by a decreased in DMI on the day before calving as well as an increase in prepartal NEFA, suggesting the lipolytic programs were in action primarily in KET cows.

\section{CONCLUSIONS}

The findings of this study revealed a potential connection between behavioral patterns derived from accelerometer data and subclinical ketosis leading to clinical ketosis. Our results support the notion of using accelerometer data to detect behavioral patterns and further correlate these prepartal data with postpartal blood BHB as an indicator of subclinical ketosis. Further research on this specific topic should strive to build prediction models based on robust data and validate these in a wide range of blood BHB concentrations from early-lactation cows.

\section{ACKNOWLEDGMENTS}

This work was partially supported by the South Dakota Agricultural Experiment Station under project No. SD00H612-16.

\section{REFERENCES}

Abuajamieh, M., S. K. Kvidera, M. V. Fernandez, A. Nayeri, N. C Upah, E. A. Nolan, S. M. Lei, J. M. DeFrain, H. B. Green, K. M. Schoenberg, W. E. Trout, and L. H. Baumgard. 2016. Inflammatory biomarkers are associated with ketosis in periparturient Holstein cows. Res. Vet. Sci. 109:81-85.

Batistel, F., J. S. Osorio, A. Ferrari, E. Trevisi, M. T. Socha, and J. J. Loor. 2016. Immunometabolic status during the peripartum period is enhanced with supplemental $\mathrm{Zn}, \mathrm{Mn}$, and $\mathrm{Cu}$ from amino acid complexes and Co from Co glucoheptonate. PLoS One 11:e0155804

Bell, A. W., W. S. Burhans, and T. R. Overton. 2000. Protein nutrition in late pregnancy, maternal protein reserves and lactation performance in dairy cows. Proc. Nutr. Soc. 59:119-126.

Bertoni, G., and E. Trevisi. 2013. Use of the liver activity index and other metabolic variables in the assessment of metabolic health in dairy herds. Vet. Clin. North Am. Food Anim. Pract. 29:413-431.

Bertoni, G., E. Trevisi, X. Han, and M. Bionaz. 2008. Effects of inflammatory conditions on liver activity in puerperium period and consequences for performance in dairy cows. J. Dairy Sci. 91:33003310.

Bionaz, M., E. Trevisi, L. Calamari, F. Librandi, A. Ferrari, and G. Bertoni. 2007. Plasma paraoxonase, health, inflammatory conditions, and liver function in transition dairy cows. J. Dairy Sci. 90:1740-1750.

Calamari, L., N. Soriani, G. Panella, F. Petrera, A. Minuti, and E. Trevisi. 2014. Rumination time around calving: An early signal to detect cows at greater risk of disease. J. Dairy Sci. 97:3635-3647.

Chapinal, N., M. Carson, T. F. Duffield, M. Capel, S. Godden, M. Overton, J. E. Santos, and S. J. LeBlanc. 2011. The association of serum metabolites with clinical disease during the transition period. J. Dairy Sci. 94:4897-4903.
Contreras, G. A., and L. M. Sordillo. 2011. Lipid mobilization and inflammatory responses during the transition period of dairy cows. Comp. Immunol. Microbiol. Infect. Dis. 34:281-289.

Drackley, J. K. 1999. ADSA Foundation Scholar Award. Biology of dairy cows during the transition period: The final frontier? J. Dairy Sci. 82:2259-2273.

Edwards, J. L., and P. R. Tozer. 2004. Using activity and milk yield as predictors of fresh cow disorders. J. Dairy Sci. 87:524-531.

Goff, J. P., K. Kimura, and R. L. Horst. 2002. Effect of mastectomy on milk fever, energy, and vitamins A, E, and beta-carotene status at parturition. J. Dairy Sci. 85:1427-1436.

Goldhawk, C., N. Chapinal, D. M. Veira, D. M. Weary, and M. A. von Keyserlingk. 2009. Prepartum feeding behavior is an early indicator of subclinical ketosis. J. Dairy Sci. 92:4971-4977.

Gu, Q., X. Yang, L. Lin, S. Li, Q. Li, S. Zhong, J. Peng, and Z. Cui. 2014. Genetic ablation of solute carrier family 7a3a leads to hepatic steatosis in zebrafish during fasting. Hepatology 60:1929-1941.

Henning, S. M., M. E. Swendseid, B. T. Ivandic, and F. Liao. 1997. Vitamins C, E and A and heme oxygenase in rats fed methyl/ folate-deficient diets. Free Radic. Biol. Med. 23:936-942.

Herdt, T. H. 2000. Ruminant adaptation to negative energy balance. Influences on the etiology of ketosis and fatty liver. Vet. Clin. North Am. Food Anim. Pract. 16:215-230. (v.).

Itle, A. J., J. M. Huzzey, D. M. Weary, and M. A. von Keyserlingk. 2015. Clinical ketosis and standing behavior in transition cows. J. Dairy Sci. 98:128-134.

Iwersen, M., U. Falkenberg, R. Voigtsberger, D. Forderung, and W. Heuwieser. 2009. Evaluation of an electronic cowside test to detect subclinical ketosis in dairy cows. J. Dairy Sci. 92:2618-2624.

Jacometo, C. B., J. S. Osorio, M. Socha, M. N. Correa, F. PiccioliCappelli, E. Trevisi, and J. J. Loor. 2015. Maternal consumption of organic trace minerals alters calf systemic and neutrophil mRNA and microRNA indicators of inflammation and oxidative stress. J. Dairy Sci. 98:7717-7729.

Kamphuis, C., E. Frank, J. K. Burke, G. A. Verkerk, and J. G. Jago. 2013. Applying additive logistic regression to data derived from sensors monitoring behavioral and physiological characteristics of dairy cows to detect lameness. J. Dairy Sci. 96:7043-7053.

Kaufman, E. I., S. J. LeBlanc, B. W. McBride, T. F. Duffield, and T. J. DeVries. 2016a. Association of rumination time with subclinical ketosis in transition dairy cows. J. Dairy Sci. 99:5604-5618.

Kaufman, E. I., S. J. LeBlanc, B. W. McBride, T. F. Duffield, and T. J. DeVries. 2016b. Short communication: Association of lying behavior and subclinical ketosis in transition dairy cows. J. Dairy Sci. 99:7473-7480.

Kokkonen, T., J. Taponen, T. Anttila, L. Syrjala-Qvist, C. Delavaud, Y. Chilliard, M. Tuori, and A. T. Tesfa. 2005. Effect of body fatness and glucogenic supplement on lipid and protein mobilization and plasma leptin in dairy cows. J. Dairy Sci. 88:1127-1141.

LeBlanc, S. 2010. Monitoring metabolic health of dairy cattle in the transition period. J. Reprod. Dev. 56(Suppl.):S29-S35.

Ledgerwood, D. N., C. Winckler, and C. B. Tucker. 2010. Evaluation of data loggers, sampling intervals, and editing techniques for measuring the lying behavior of dairy cattle. J. Dairy Sci. 93:5129-5139.

Loor, J. J., G. Bertoni, A. Hosseini, J. R. Roche, and E. Trevisi. 2013. Functional welfare - using biochemical and molecular technologies to understand better the welfare state of peripartal dairy cattle. Anim. Prod. Sci. 53:931-953.

McArt, J. A., D. V. Nydam, and G. R. Oetzel. 2013a. Dry period and parturient predictors of early lactation hyperketonemia in dairy cattle. J. Dairy Sci. 96:198-209.

McArt, J. A., D. V. Nydam, G. R. Oetzel, T. R. Overton, and P. A. Ospina. 2013b. Elevated non-esterified fatty acids and betahydroxybutyrate and their association with transition dairy cow performance. Vet. J. 198:560-570.

McLaren, C. J., K. D. Lissemore, T. F. Duffield, K. E. Leslie, D. F. Kelton, and B. Grexton. 2006. The relationship between herd level disease incidence and a return over feed index in Ontario dairy herds. Can. Vet. J. 47:767-773. 
NRC. 2001. Nutrient Requirements of Dairy Cattle. Vol. 7. Natl. Acad. Press, Washington, DC.

Oetzel, G., and S. McGuirk. 2008. Evaluation of a hand-held meter for cowside evaluation of blood beta-hydroxybutyrate and glucose concentrations in dairy cows. Page 234 in Proc. 41st Annu. Conf., Am. Assoc. Bov. Pract. Am. Assoc. Bov. Pract., Auburn, AL.

Oh, H. J., T. H. Kim, Y. W. Sohn, Y. S. Kim, Y. R. Oh, E. Y. Cho, S. Y. Shim, S. R. Shin, A. L. Han, S. J. Yoon, and H. C. Kim. 2011. Association of serum alanine aminotransferase and gamma-glutamyltransferase levels within the reference range with metabolic syndrome and nonalcoholic fatty liver disease. Korean J. Hepatol. $17: 27-36$.

Osorio, J. S., E. Trevisi, C. Li, J. K. Drackley, M. T. Socha, and J. J. Loor. 2016. Supplementing $\mathrm{Zn}, \mathrm{Mn}$, and $\mathrm{Cu}$ from amino acid complexes and Co from cobalt glucoheptonate during the peripartal period benefits postpartal cow performance and blood neutrophil function. J. Dairy Sci. 99:1868-1883.

Ospina, P. A., D. V. Nydam, T. Stokol, and T. R. Overton. 2010 Evaluation of nonesterified fatty acids and beta-hydroxybutyrate in transition dairy cattle in the northeastern United States: Critical thresholds for prediction of clinical diseases. J. Dairy Sci. 93:546-554.

Rutten, C. J., A. G. Velthuis, W. Steeneveld, and H. Hogeveen. 2013. Invited review: Sensors to support health management on dairy farms. J. Dairy Sci. 96:1928-1952.

Schweigert, F. J. 2001. Inflammation-induced changes in the nutritional biomarkers serum retinol and carotenoids. Curr. Opin. Clin. Nutr. Metab. Care 4:477-481.
Seifi, H. A., S. J. Leblanc, K. E. Leslie, and T. F. Duffield. 2011. Metabolic predictors of post-partum disease and culling risk in dairy cattle. Vet. J. 188:216-220.

Sharma, J. N., A. Al-Omran, and S. S. Parvathy. 2007. Role of nitric oxide in inflammatory diseases. Inflammopharmacology 15:252259

Soriani, N., E. Trevisi, and L. Calamari. 2012. Relationships between rumination time, metabolic conditions, and health status in dairy cows during the transition period. J. Anim. Sci. 90:4544-4554.

Susenbeth, A., T. Dickel, K. H. Sudekum, W. Drochner, and H. Steingass. 2004. Energy requirements of cattle for standing and for ingestion, estimated by a ruminal emptying technique. J. Anim. Sci. 82:129-136.

Trevisi, E., M. Amadori, S. Cogrossi, E. Razzuoli, and G. Bertoni. 2012. Metabolic stress and inflammatory response in high-yielding, periparturient dairy cows. Res. Vet. Sci. 93:695-704.

Trevisi, E., N. Jahan, G. Bertoni, A. Ferrari, and A. Minuti. 2015. Pro-inflammatory cytokine profile in dairy cows: Consequences for new lactation. Ital. J. Anim. Sci. 14:285-292. https://doi.org/10 .4081/ijas.2015.3862.

Trevisi, E., L. Moscati, and M. Amadori. 2016. Chapter 9-Diseasepredicting and prognostic potential of innate immune responses to noninfectious stressors: Human and animal models. Pages 209-235 in The Innate Immune Response to Noninfectious Stressors. Acad. Press, Cambridge, MA.

Weary, D. M., J. M. Huzzey, and M. A. von Keyserlingk. 2009. Boardinvited review: Using behavior to predict and identify ill health in animals. J. Anim. Sci. 87:770-777. 